Досліджено закономірності осадження смолистих речовин зі стічних вод коксохімічних підприємств при гетерокоагуляиї коагулянтами $\mathrm{FeCl}_{3} \mathrm{i} \mathrm{Al}_{2}(\mathrm{OH})_{5} \mathrm{Cl}$, та бентонітовою глиною сумісно з флокулянтом Extraflock P70. Методом седиментаційного аналізу встановлені ивидкість осадження та переважні радіуси полютант-вмісних агрегатів дисперсної фази стічних вод. Отримані результати дозволяють удосконалити процес очищення фенольних вод на коксохімічних підприємствах

Ключові слова: седиментачійний аналіз, бентонітова глина, стічні води коксохімічних підприємств, смолисті речовини, коагулянт, флокулянт

Исследованы закономерности осаждения смолистых веществ из сточных вод коксохимических при гетерокоагуляции коагулянтами $\mathrm{FeCl}_{3}$ и $\mathrm{Al}_{2}(\mathrm{OH})_{5} \mathrm{Cl}$, и бентонитовой глиной совместно с флокулянтом Extraflock P70. Методом седиментационного анализа установлены скорость осаждения и преимущественные радиусы полютант-содержащих агрегатов дисперсной фазы сточных вод. Полученные результаты позволяют усовершенствовать процесс очистки фенольных вод на коксохимических предприятиях

Ключевые слова: седиментационный анализ, бентонитовая глина, сточные водь коксохимических предприятий, смолистые вещества, коагулянт, флокулянт

\title{
SEDIMENTATION OF POLLUTANT-CONTAINING AGGREGATES DURING PURIFICATION OF WASTEWATER FROM COKING PLANTS
}

\author{
D. Yelatontsev \\ Postgraduate student* \\ E-mail: sauron11652@gmail.com \\ V. S u pru n ch u k \\ $\mathrm{PhD}$, Associate Professor \\ Department of Inorganic Substances, \\ Water Purification and General Chemical Technology \\ National Technical University of Ukraine \\ «lgor Sikorsky Kyiv Polytechnic Institute» \\ Peremohy ave., 37, Kyiv, Ukraine, 03056 \\ E-mail: Olenalvanyuk@ukr.net \\ M. Voloshin \\ Doctor of Technical Sciences, \\ Professor, Head of Department* \\ E-mail: voloshin@ua.fm \\ *Department of Chemical Technology of Inorganic Substances \\ Dniprovsk State Technical University \\ Dniprobudivska str., 2, Kamianske, Ukraine, 49000
}

\section{Introduction}

The extremely negative impact of coke-chemical enterprises wastewater (due to significant pollution by phenol, called phenolic) is a well-known fact. Numerous scientific papers [1-12] describe it. There are many coke enterprises in Dnipropetrovsk and especially Donetsk regions. A scale of a damaging influence of a mentioned type of man-made waste on the environment is a source of concern for the population of the regions.

Previous studies [1] determined reasons for poor performance of the purification of phenolic wastewater from phenols, rhodanates and cyanides. The main reason is the lack of efficiency of removal of resins at the stage of mechanical purification. Experiments proved the effectiveness of the reagent flotation method with a use of coagulants: $\mathrm{Al}_{2}(\mathrm{OH})_{5} \mathrm{Cl}, \mathrm{Al}_{2}\left(\mathrm{SO}_{4}\right)_{3}, \mathrm{AlCl}_{3}, \mathrm{FeSO}_{4}, \mathrm{Fe}_{2}\left(\mathrm{SO}_{4}\right)_{3}$ and $\mathrm{FeCl}_{3}$ [2]. Treatment with alkaline bentonite clay with the addition of cationic flocculant reduced a content of resins to modern requirements for disposal of sludges in construction of road pavements [3]. This article considers a quantitative description of processes, which occur in the medium of phenolic wastewater during their purification with a use of coagulants, flocculants and bentonite clays.
The literature does not reveal quantitative characteristics of sedimentation of pollutant-containing aggregates of the dispersed phase of phenolic wastewater. Therefore, it is not possible to improve a process of wastewater purification from resins purposefully. Detection of quantitative characteristics of the sedimentation process determines the expedience of the study.

\section{Literature review and problem statement}

Typical and most common method of purification of phenolic waters from resinous substances is flotation with an addition of special reagents (coagulants or flocculants) [1-3].

Reagent flotation involves the delivery of coagulant solutions to flotators during passing of air through contaminated water. As a result, processes of coagulation, coalescence and oxidation of most organic substances intensify. The best reagents for this purpose are ferrum salts: $\mathrm{FeCl}_{3}, \mathrm{FeSO}_{4}$, and others. Work proves [4] that the use of $\mathrm{FeCl}_{3}$ during reagent flotation with removal of resinous substances leads to a significant decrease in chemical consumption of oxygen (by $56.37 \%$ at $\mathrm{pH}=9$ ), which allws the authors to argue about the oxidation of a part of organic compounds to mineral 
ones, which is significantly less harmful. The main disadvantage of the method is a difficulty connected with the disposal of flotation sludges, which are sources of pollution of the environment by heavy metal ions and polycyclic aromatic hydrocarbons (PAH).

We can achieve a simultaneous removal of resinous and suspended matter from wastewater even at very high initial concentrations (196 and $1,123 \mathrm{mg} / \mathrm{dm}^{3}$, respectively) due to the use of flocculants based on polyacrylamide. Rather high cost restrains large-scale use of flocculants. Although there are active developments on application of flocculants made of natural substances (chitosan, starch, lignin, etc.) [5].

World experience [6-11] in the development of new technologies for water purification contaminated with organic substances, which are capable of forming stable emulsions, proves the expediency of the use of various types of natural disperse minerals (bentonite, glauconite or paligrosite clays). Clays can be used both in natural form and after special activation (modification of clay surface with surfactants or special inorganic substances).

In the context of the study, the main scientific interest is the study of purification of waste water from organic compounds, which are similar to resinous substances in properties, in particular, $\mathrm{PAH}$.

in the course of studies on adsorption of naphthalene from aqueous solutions with natural and bentonite-modified hexadecyltrimethylammonium bromide (TTAB-Mt), paper [6] found that the latter is an effective sorbent of this substance, especially at $\mathrm{pH}$ equal to 4.00 and 5.97 , respectively. Under conditions of a purification process at coke enterprises, such a low $\mathrm{pH}$ value is irrational (the reaction of the medium lies within the range of 7.3-8.3). The adsorption capacity of TTAB-Mt in relation to $\mathrm{PAH}$ decreases in the range of xylene $>$ ethylbenzene $>$ toluene $>$ benzene [7]. It is naphthalene that defines physical and chemical properties of resins as the main component of an identified part of a chemical composition [8]. As a result of modification, the interlayer distance of a crystalline bentonite lattice expands from $1.152 \mathrm{~nm}$ to $2.175 \mathrm{~nm}$ [9], which increases a specific surface of particles of clay. During concurrent application of bentonite and TTAB modifier, along with the removal of PAH, we get binding of $90 \%$ of phenols due to $\pi-\pi$ interaction. The adsorption capacity of the modified bentonite is increased by 10 times, and the regeneration of the spent sorbent is almost $100 \%$ [10].

Work [11] shows that there are inorganic modifiers located in the range of salt $<$ alkali $<$ acid according to a level of the increase in the adsorption activity of modified bentonite in relation to naphthalene. Because acid-modified $\mathrm{HCl}$ bentonite significantly increases a specific surface area and total pore volume, it is considered a promising sorbent for purification of liquid media from PAH.

The listed methods of modification of bentonite presuppose a presence of appropriate modifying agents, which are very expensive. This circumstance limits the development of a use of activated bentonite sorbents substantially, especially in a case of large amounts of wastewater. Therefore, a special object of a scientific interest is a use of bentonite in a natural state, without modification. Paper [1] gives positive results obtained during purification of wastewater of coke plants from resinous substances using natural bentonite clay. But the paper uses empirical data for a description of the purification processes and does not reveal quantitative characteristics of flocculation and adsorption purification.

\section{The aim and objectives of the study}

The aim of present study is to reveal objective laws of processes of coagulation, flocculation and adsorption purification of wastewater of coke-chemical enterprises from resinous substances.

The achievement of the objective set involves solution of the following tasks:

- obtaining of dependences of the mass of sediment pollutant-containing aggregates of a dispersed phase on the time of sedimentation during coagulation, flocculation and adsorption purification of phenolic wastewater;

- calculation of a prevailing radius of pollutant-containing aggregates by the method of graphical processing of results of sedimentation analysis;

- determination of the most effective way to purify phenolic wastewater on the basis of a comparative analysis of the sedimentation rate and geometric sizes of pollutant-containing aggregates of different types.

\section{Materials and methods of the study of wastewater of} coke enterprises by the method of sedimentation analysis

\section{1. Substances and equipment used in the study}

The study used phenolic wastewater from PJSC "Dneprovsky CCF" (Ukraine). The following indicators characterized the wastewater (Table 1).

Table 1

Physical and chemical characteristics of the phenolic wastewater under study

\begin{tabular}{|c|c|}
\hline Characteristic & Value \\
\hline Resinous substances, $\mathrm{mg} / \mathrm{dm}^{3}$ & 265 \\
\hline Suspended matter, $\mathrm{mg} / \mathrm{dm}^{3}$ & 520 \\
\hline $\begin{array}{c}\text { COD }(\text { chemical oxygen } \\
\text { demand }), \mathrm{mg}\left(\mathrm{O}_{2}\right) / \mathrm{dm}^{3}\end{array}$ & 4,800 \\
\hline Phenols, $\mathrm{mg} / \mathrm{dm}^{3}$ & 500 \\
\hline $\mathrm{pH}$ & 8.2 \\
\hline Density, $\mathrm{kg} / \mathrm{m}^{3}$ & 993 \\
\hline Viscosity, $\mathrm{mPa} \cdot \mathrm{s}$ & 0.774 \\
\hline Color & Dark grayish brown \\
\hline
\end{tabular}

As we can see from Table 1, the content of the main pollutants in the studied wastewater corresponded the average regulatory content in the industry with a slight excess of the regulatory content of resinous substances [12]. During experiments, we maintained wastewater temperature at a temperature of $323 \pm 2 \mathrm{~K}$ in a thermostat (identical to industrial conditions). We determined the concentration of resinous substances in phenolic wastewater photometrically according to the methodology developed by the state enterprise "Ukrainian State Research Carbon Institute" (UCIN) No. 63.08.

We used technical aluminum hydroxy chloride Polvac-68 (TU U 19155069.001-1999) and ferrum (III) chloride (TU U 24.1-05444552-045-2005) as coagulants. The cationic flocculant was Extrafloc P70 product based on polyacrylamide produced by Open Joint-Stock Company PCF “Coagulant" (TU U 24.1-19155069-014-2011). We used bentonite clay with a mass fraction of alkaline metals $(\mathrm{Na}+\mathrm{K})$ at recalculation to their oxides of $3.9 \%$, with a true density of $2,199 \mathrm{~kg} / \mathrm{m}^{3}$, manufactured by LLC "Filtr Prom Company" (TU U 320.00136751.032-1999). 
The dosage of coagulants was $50 \mathrm{mg} / \mathrm{dm}^{3}$ of a main active substance $\left(\mathrm{Al}_{2}(\mathrm{OH})_{5} \mathrm{Cl}\right.$ and $\mathrm{FeCl}_{3}$, respectively) with an air supply intensity equal to $0.5 \mathrm{~m}^{3} / \mathrm{m}^{3}$ and a wastewater volume of $0.5 \mathrm{dm}^{3}$. We mixed coagulants with wastewater pneumatically by bubbling of air through dispersants - glass filters of Schott No. 2. Duration of bubbling was 20 minutes, after which purified water and sludge became a subject to sedimentation analysis.

In the study of phenolic water flocculation with the use of Extrafloc P70 at a dosage of $4 \mathrm{mg} / \mathrm{dm}^{3}$, we applied JarTest method [13], according to which the stirring rate was $350 \mathrm{rpm}$ during first $60 \mathrm{~s}$, and 50-60 rpm within the next 20 minutes. After that, we stirred the purified wastewater again, together with a sediment, in a mode of $350 \mathrm{rpm}$ for $15 \mathrm{~s}$ and poured it into a glass container with a height of $25 \mathrm{~cm}$, which was located in a thermostat. We placed a cup of torsion scales into a tank with a suspension for 5 seconds at a depth of $H=0.155 \mathrm{~m}$. We measured the mass of sediment pollutant-containing aggregates at intervals of $15 \ldots 60 \mathrm{~s}$. We used VT-500 torsion scales of the III class of accuracy with a weighing limit of $0.5 \mathrm{~g}$ and an absolute error of $\pm 10^{-3} \mathrm{~g}$ in the course of sedimentation analysis.

We carried out the adsorption study under static conditions in a reactor of $0.5 \mathrm{dm}^{3}$ at a stirring rate of $250 \mathrm{rpm}$, with Extrafloc P70 flocculant at a dosage of $4 \mathrm{mg} / \mathrm{dm}^{3}$; a dosage of alkaline bentonite clay was $100 \mathrm{mg} / \mathrm{dm}^{3}$. The process of adsorption went until formation of a clearly visible sediment and clarification of phenolic water (from 1 to 3 minutes). After that, we subjected water together with the sediment of a total volume of $0.5 \mathrm{dm}^{3}$ to sedimentation analysis using the above methodology.

We performed the regression analysis of the experimental data, the construction of diagrams and the calculation of reliability values of the approximation in the Microsoft Excel 2016 environment.

\section{2. Methods of data processing for sedimentation} analysis

There were three forces, which influenced a spherical particle precipitated in a viscous medium: the gravity directed downward and two forces directed upwards: the strength of Archimedes and the strength of a viscous resistance (Stokes force). We can write the equation (1) describing the combined effect of mentioned three forces as follows [14]:

$$
\frac{4 \pi r^{3}}{3} \rho g=\frac{4 \pi r^{3}}{3} \rho_{0} g+6 \pi r \eta u
$$

after its transformation, we obtain the equation (2) for calculation of rate of a motion of pollutant-containing aggregates [14]:

$$
u=\frac{2\left(\rho-\rho_{0}\right) g}{9 \eta} r^{2}
$$

where $u$ is the rate of aggregate sedimentation, $\mathrm{m} / \mathrm{s} ; \rho$ and $\rho_{0}$ are the densities of a disperse phase and a dispersion medium, respectively, $\mathrm{kg} / \mathrm{m}^{3} ; g$ is acceleration of gravity, $\mathrm{m} / \mathrm{s}^{2}$; $\eta$ is the viscosity of a dispersion medium, Pa.s; $r$ is an equivalent radius of a spherical aggregate, $\mathrm{m}$.

If characteristics of a dispersion medium $\left(\rho_{0}, \eta\right)$, a disperse phase $(\rho)$ and rate of sedimentation of pollutant-containing aggregates of a disperse phase $u$ are known, we obtain the equation (3) for calculation of a radius using the transformation of equation (2) [14]:

$$
r=\sqrt{\frac{9 \eta u}{2\left(\rho-\rho_{0}\right) g}} .
$$

We can simplify the equation (3) if we combine all stable under given conditions values in a constant $K$. As a result, we obtain the working equation (4):

$$
r=K \sqrt{u}
$$

where the rate of sedimentation of pollutant-containing aggregates $u$ is equal to the ratio of a height $H(\mathrm{~m})$ to duration $\tau(\mathrm{s})$ of sedimentation (we determined these values experimentally).

Based on the data obtained with the use of torsion scales, we construct a sedimentation curve - the dependence of the mass of pollutant-containing aggregates $m$, which precipitated, on the time of sedimentation $\tau$. Then we process the curve graphically to construct differential and integral curves for the distribution of pollutant-containing aggregates by sizes [14].

We calculate the density of the pollutant-containing aggregates on the basis of values of the density of a dry dispersed phase, taking into account its moisture content by the rule of addiction. We determine the moisture content of sediments gravimetrically by drying at a temperature of $105^{\circ} \mathrm{C}$ to constant mass. Since values of the density and the viscosity of a dispersion medium remained almost unchanged during the use of different reagents, we determine the value of the constant $K$ mainly by the dispersion phase density, which was determined by the picnometry method (Table 2).

Table 2

Dependence of values of constant $K$ on the density of pollutant-containing aggregates

\begin{tabular}{|c|c|c|c|c|c|}
\hline Indicator & $\mathrm{Al}_{2}(\mathrm{OH})_{5} \mathrm{Cl}$ & $\mathrm{FeCl}_{3}$ & $\begin{array}{c}\text { Benton- } \\
\text { ite clay }\end{array}$ & $\begin{array}{c}\text { Extra- } \\
\text { floc P70 }\end{array}$ & $\begin{array}{c}\text { Bentonite } \\
\text { clay+Extra- } \\
\text { floc P70 }\end{array}$ \\
\hline $\begin{array}{c}\text { Density of } \\
\text { a dry solid } \\
\text { phase, } \mathrm{kg} / \mathrm{m}^{3}\end{array}$ & 1,916 & 2,900 & 2,199 & 1,302 & 1,900 \\
\hline $\begin{array}{c}\text { Moisture, } \\
\text { mass fraction }\end{array}$ & 0.65 & 0.46 & 0.56 & 0.68 & 0.63 \\
\hline $\begin{array}{c}\text { Density, } \\
\mathrm{kg} / \mathrm{m}^{3}\end{array}$ & 1,193 & 1,529 & 1,308 & 1,076 & 1,207 \\
\hline $\mathrm{K} \cdot 10^{-4}$ & 13.34 & 8.14 & 10.62 & 20.72 & 12.87 \\
\hline
\end{tabular}

Thus, with an increase in the density of pollutant-containing aggregates formed with the use of different reagents, a value of the constant $K$ decreases.

\section{Results of the study on the process of purification of wastewater of coke-chemical enterprises by the method of sedimentation analysis}

At the first stage of the study, we obtained sedimentation curves of the pollutant-containing aggregates of the dispersed phase of phenolic wastewater after purification by various methods. Fig. 1 shows the general view of curves. 


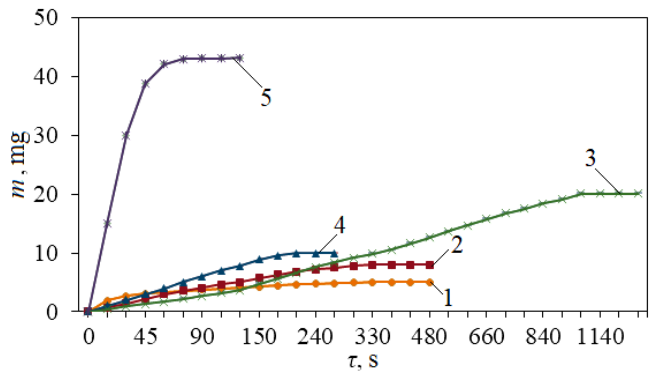

Fig. 1. Dependence of the mass of sediment pollutant-containing aggregates of the dispersed phase $m$ on the duration of the process $\tau$ : 1 - coagulation with the use of $\mathrm{Al}_{2}(\mathrm{OH})_{5} \mathrm{Cl}$ at a dosage of $50 \mathrm{mg} / \mathrm{dm}^{3}$; 2 - coagulation with the use of $\mathrm{FeCl}_{3}$ at a dosage of $50 \mathrm{mg} / \mathrm{dm}^{3}$; 3 - adsorption of bentonite clay at a dosage of $100 \mathrm{mg} / \mathrm{dm}^{3}$; $4-$ flocculation with the use of Extrafloc P70 at a dosage of $4 \mathrm{mg} / \mathrm{dm}^{3} ; 5-$ adsorption of bentonite clay at a dosage of $100 \mathrm{mg} / \mathrm{dm}^{3}$ with the addition of Extrafloc P70 at a dosage of $4 \mathrm{mg} / \mathrm{dm}^{3}$

Using equation (4) at a height of the immersion of a cup of torsion scales $H=0.155 \mathrm{~m}$ for values of the constant $K$ of pollutant-containing aggregates (Table 2), we constructed integral curves for the distribution of the dispersed phase of purified wastewater according to radii (Fig. 2-6).

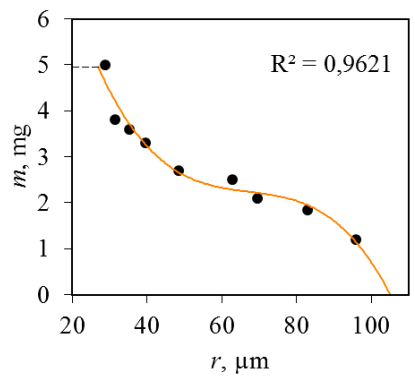

Fig. 2. Integral distribution curve of pollutant-containing aggregates of the dispersed phase of wastewater by radii after coagulation with the use of $\mathrm{Al}_{2}(\mathrm{OH})_{5} \mathrm{Cl}$ at a dosage of

$50 \mathrm{mg} / \mathrm{dm}^{3}\left[m=-0.0003 r^{3}+0.007 r^{2}-0.4837 r+13.561\right]$

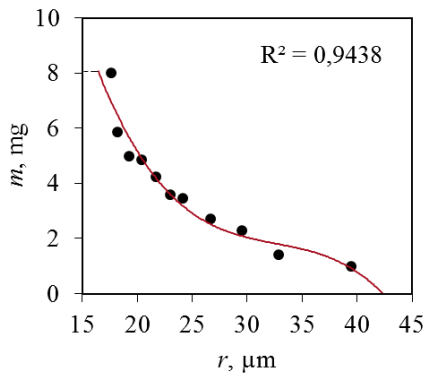

Fig. 3. Integral distribution curve of pollutant-containing aggregates of the dispersed phase of wastewater by radii

after coagulation with the use $\mathrm{FeCl}_{3}$ at a dosage of

$50 \mathrm{mg} / \mathrm{dm}^{3}\left[m=-0.0012 r^{3}+0.1154 r^{2}-3.8452 r+45.331\right]$

Experimental data show that sizes (Fig. 2-6) and density (Table 2) of pollutant-containing aggregates determine their sedimentation time. Fig. 1 shows this.

Differential distribution curves by radii presented in Fig. 7-11 give a clearer idea of the value of predominant content of pollutant-containing aggregates of the specified radii.

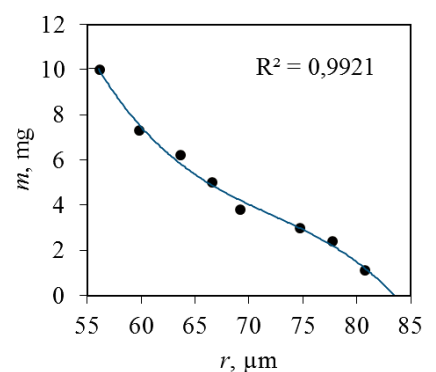

Fig. 4. Integral distribution curve of pollutant-containing aggregates of the dispersed phase of wastewater by radii after flocculation with the use of Extrafloc P70 at a dosage of $4 \mathrm{mg} / \mathrm{dm}^{3}\left[m=-0.0007 r^{3}+0.1573 r^{2}-11.55 r+291.32\right]$

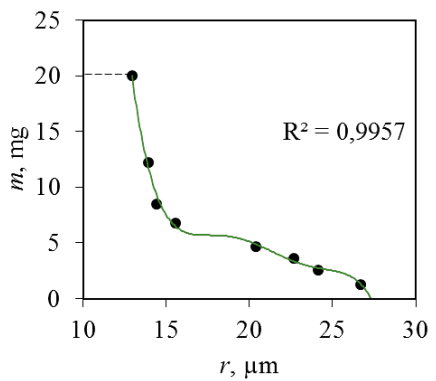

Fig. 5. Integral distribution curve of pollutant-containing aggregates of the dispersed phase of wastewater by radii after adsorption by bentonite clay at a dosage of $100 \mathrm{mg} / \mathrm{dm}^{3}\left[m=-0,0007 r^{5}+0,0786 r^{4}-3,2979 r^{3}+\right.$ $\left.+68,505 r^{2}-704,68 r+2878,9\right]$

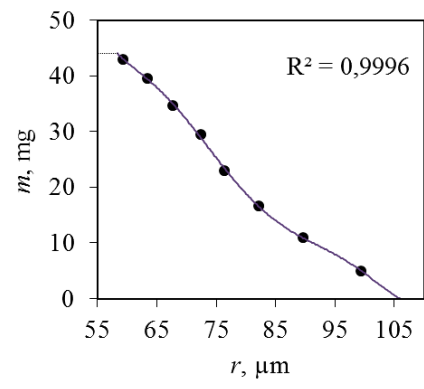

Fig. 6. Integral distribution curve of pollutant-containing aggregates of the dispersed phase of wastewater by radii after adsorption by bentonite clay at a dosage of

$100 \mathrm{mg} / \mathrm{dm}^{3}$ with the addition of Extrafloc P70 at a dosage of $4 \mathrm{mg} / \mathrm{dm}^{3}\left[m=-0,0007 r^{6}-0,0003 r^{5}+0,0071 r^{4-}\right.$ $\left.-0,7587 r^{3}+45,055 r^{2}-1409,2 r+18206\right]$

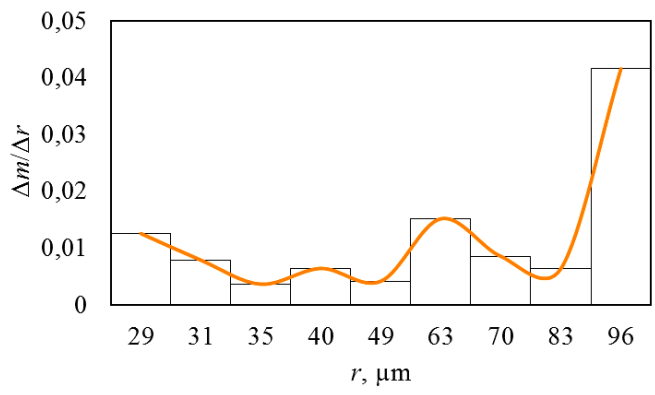

Fig. 7. Differential distribution curve of pollutant-containing aggregates of the dispersed phase of wastewater by radii after coagulation with the use of $\mathrm{Al}_{2}(\mathrm{OH})_{5} \mathrm{Cl}$ at a dosage of $50 \mathrm{mg} / \mathrm{dm}^{3}$ 


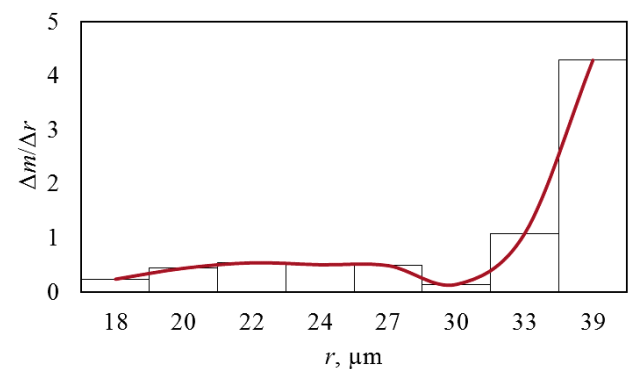

Fig. 8. Differential distribution curve of pollutant-containing aggregates of the dispersed phase of wastewater by radii after coagulation with the use of $\mathrm{FeCl}_{3}$ at a dosage of $50 \mathrm{mg} / \mathrm{dm}^{3}$

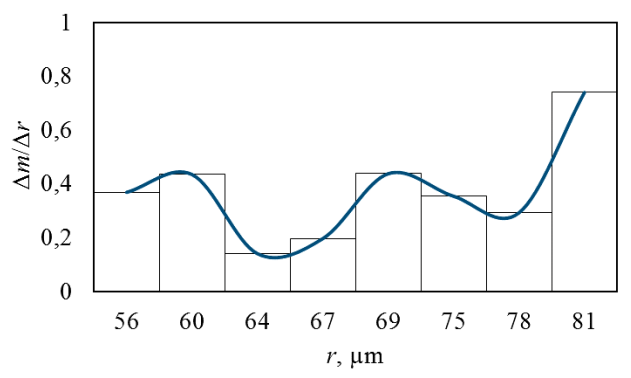

Fig. 9. Differential distribution curve of pollutant-containing aggregates of the dispersed phase of wastewater by radii after flocculation with the use of Extrafloc P70 at a dosage of $4 \mathrm{mg} / \mathrm{dm}^{3}$

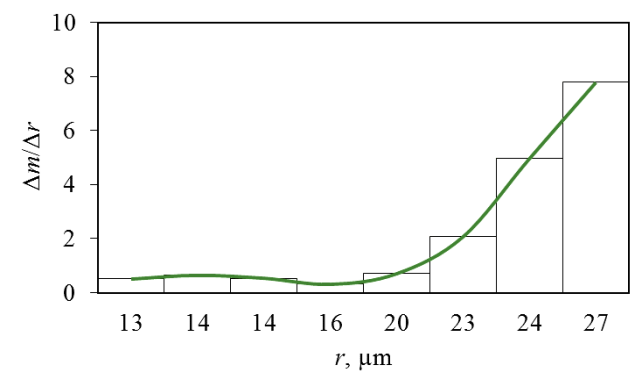

Fig. 10. Differential distribution curve of pollutant-containing aggregates of the dispersed phase of wastewater by radii after adsorption with bentonite clay at a dosage of $100 \mathrm{mg} / \mathrm{dm}^{3}$

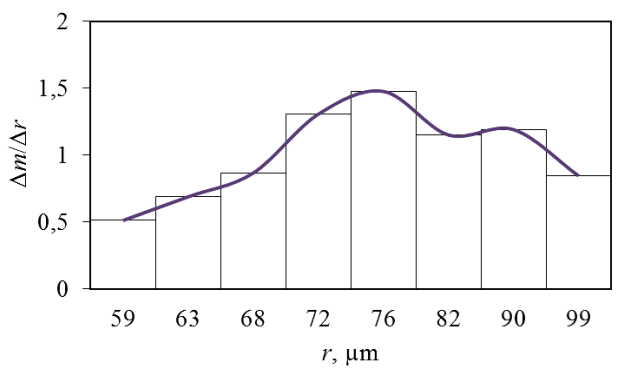

Fig. 11. Differential distribution curve of pollutant-containing aggregates of the dispersed phase of wastewater by radii after adsorption by bentonite clay at a dosage of $100 \mathrm{mg} / \mathrm{dm}^{3}$ with the addition of Extrafloc P70 at a dosage of $4 \mathrm{mg} / \mathrm{dm}^{3}$

The main indicator of the efficiency of the investigated purification methods is the content of resinous substances in purified water. Table 3 presents the results of purification of phenolic water.
Table 3

The content of resinous substances after purification by various methods

\begin{tabular}{|c|c|c|}
\hline \multirow{2}{*}{ Purification method } & \multicolumn{2}{|c|}{$\begin{array}{l}\text { Concentration of resin- } \\
\text { ous substances, } \mathrm{mg} / \mathrm{dm}^{3}\end{array}$} \\
\hline & Initial & $\begin{array}{l}\text { In purified } \\
\text { water }\end{array}$ \\
\hline $\begin{array}{c}\text { Coagulation with the use of } \mathrm{Al}_{2}(\mathrm{OH})_{5} \mathrm{Cl} \\
\text { at a dosage of } 50 \mathrm{mg} / \mathrm{dm}^{3}\end{array}$ & \multirow{5}{*}{265} & 9 \\
\hline $\begin{array}{c}\text { Coagulation with the use of } \mathrm{FeCl}_{3} \\
\text { at a dosage of } 50 \mathrm{mg} / \mathrm{dm}^{3}\end{array}$ & & 18 \\
\hline $\begin{array}{l}\text { The use of Extrafloc P70 } \\
\text { at a dosage of } 4 \mathrm{mg} / \mathrm{dm}^{3}\end{array}$ & & 35 \\
\hline $\begin{array}{l}\text { Adsorption by bentonite } \\
\text { at a dosage of } 100 \mathrm{mg} / \mathrm{dm}^{3}\end{array}$ & & 50 \\
\hline $\begin{array}{l}\text { Adsorption by bentonite at a dosage of } \\
100 \mathrm{mg} / \mathrm{dm}^{3} \text { with the addition of Extra- } \\
\text { floc P70 at a dosage of } 4 \mathrm{mg} / \mathrm{dm}^{3}\end{array}$ & & 10 \\
\hline
\end{tabular}

As we can see from Table 3 , the content of resinous substances in purified wastewater is least when we use $\mathrm{Al}_{2}(\mathrm{OH})_{5} \mathrm{Cl}$ and bentonite clay with the addition of Extrafloc P70. At the same time, when we use $\mathrm{Al}_{2}(\mathrm{OH})_{5} \mathrm{Cl}$, the sedimentation of pollutant-containing aggregates occurs very slowly (Fig. 1), and we do not observe the clarification of water due to the fact that dispersed aggregates of small density are usually formed (Table 2). When we use bentonite clay with the addition of Extrafloc P70, the size of pollutant-containing aggregates increases, which leads to a quick clarification of water (Fig. 1).

\section{Discussion of results of sedimentation analysis of wastewater of coke-chemical enterprises}

Turning to integral distribution curves of pollutant-containing aggregates of the dispersed phase (Fig. 2-6), it is necessary to emphasize their general similarity to each other and the absence of abnormal sections. We also should note that the starting point of mass distribution of pollutant-containing aggregates by radii is different in all cases. And this fact shows unevenness of aggregate contents per unit volume of wastewater in presence of various reagents. For example, we observed the highest content of pollutant-containing aggregates when we used bentonite clay ( $43 \mathrm{mg}$ per $500 \mathrm{~cm}^{3}$ of phenolic water) with the addition of Extrafloc P70, which is the result of combined precipitation of bentonite clay and organic pollutants.

It is noteworthy that a significant $(\sim 80 \mathrm{~s})$ reduction in the duration of sedimentation occurs at the simultaneous use of bentonite clay and flocculant (Fig. 1), which is well consistent with previous studies [1]. The reason for this phenomenon is the interaction of hydrophilic coagulants containing alkaline bentonite clay with Extrafloc P70 polymer structures, which leads to sediment formation with high sedimentation properties. A significant difference in the true density of bentonite clay and phenolic water also contribute this. The mechanism of the process is as follows: amide functional groups of cationic type of Extrafloc P70 bind to surface hydroxide bentonite groups due to forces of electrostatic interaction. As a result, there is the formation of larger pollutant-containing aggregates (flocculus).

Favorable temperature conditions accelerate the process also. The temperature of phenolic water is $323 \mathrm{~K}$ on 
average. Data on sedimentation confirm aggregation. The most probable radius of pollutant-containing aggregates increases (Fig. 11). Extrafloc P70 binds particles not only to bentonite, but also to suspended matter, coke and other dispersed contaminants, which results in purification and clarification of phenolic water. At the same time adsorption of resinous substances by the surface of pollutant-containing aggregates of bentonite goes. The prevailing radius of pollutant-containing aggregates of the dispersed phase increases to $70 \ldots 90 \mu \mathrm{m}$.

At the same time, the duration of sedimentation of the dispersed phase in the presence of bentonite clay is the longest ( $20 \mathrm{~min})$ because a suspension with the smallest radius of pollutant-containing aggregates is formed $-23 \ldots 27 \mu \mathrm{m}$ (Fig. 10) in this case.

The duration of sedimentation of the dispersed phase with the addition of Extrafloc P70 is 210 s only. There are units of a prevailing radius of $60 \ldots 80 \mu \mathrm{m}$ formed during it. That is, the deposition time correlates with sizes of pollutant-containing aggregates. At the same time, when using Extrafloc P70 only, the duration of sedimentation is greater than when using bentonite clay with the addition of Extrafloc P70 by 3.5 times. This is due to an increase in the prevailing radius from $60 \ldots 80 \mu \mathrm{m}$ to $70 \ldots 90 \mu \mathrm{m}$ (Fig. 9,11). Even more reduction in the duration of deposition (by 15 times) occurs due to an increase in the prevailing radius from $23 \ldots 27 \mu \mathrm{m}$ in the presence of bentonite clay only, up to $70 \ldots 90 \mu \mathrm{m}$ with the addition of Extrafloc P70.

We should note that there is a significant difference in the sediment mass, which precipitates, at the same time intervals in the presence of various reagents (Fig. 1). This mass exceeds all others by $2.5-8$ times for bentonite+flocculant. This fact indicates the deposition of aggregated pollutant-containing aggregates with a large radius $(70 \ldots 90 \mu \mathrm{m})$ and observed intensive clarification of phenol water. The use of other methods of purification of phenolic waters applied in this study does not lead to clarification of water at all.

When using $\mathrm{FeCl}_{3}$ coagulant, an average size of pollutant-containing aggregates (Fig. 8) is $33 \ldots 39 \mu \mathrm{m}$, which significantly reduces sedimentation rate of ferrum-containing aggregates. We assume that Fe(III) ions form more dispersed particles under such purification conditions. They have lower affinity with pollution of phenolic waters compared with other reagents. A high value $\left(18 \mathrm{mg} / \mathrm{dm}^{3}\right)$ of residual concentrations of resinous substances confirms this (Table 3 ).

Comparing the efficiency of removal of resinous substances by the use of different methods, we should take into account that the maximum permissible concentration of such substances in purified water should be less than $25 \mathrm{mg} / \mathrm{dm}^{3}[1,2]$. Data from Table 3 shows that we can achieve a required degree of purification using coagulants $\mathrm{Al}_{2}(\mathrm{OH})_{5} \mathrm{Cl}$ and $\mathrm{FeCl}_{3}$, as well as in processing with bentonite clay with the addition of Extrafloc P70. We should dive an advantage to the last of the methods, because the cost of bentonite clay in Ukraine today is 5-10 times lower than the cost of $\mathrm{Al}_{2}(\mathrm{OH})_{5} \mathrm{Cl}$ or $\mathrm{FeCl}_{3}$. In addition, bentonite clay and flocculants, unlike coagulants, do not accelerate the development of corrosion of purifying equipment.

\section{Conclusions}

1. Sedimentation analysis of the disperse phase of purification of phenol wastewater showed that the integral rate of sedimentation of pollutant-containing aggregates is, $\mathrm{mg} / \mathrm{s}: \mathrm{Al}_{2}(\mathrm{OH})_{5} \mathrm{Cl}$ at a dosage of $50 \mathrm{mg} / \mathrm{dm}^{3}-0.017$; $\mathrm{FeCl}_{3}$ at a dosage of $50 \mathrm{mg} / \mathrm{dm}^{3}-0.024$; Extrafloc P70 at a dosage of $4 \mathrm{mg} / \mathrm{dm}^{3}-0.05$; bentonite clay at a dosage of $100 \mathrm{mg} / \mathrm{dm}^{3}-0.02$; bentonite clay at a dosage of $100 \mathrm{mg} / \mathrm{dm}^{3}$ with the addition of Extrafloc P70 at a dosage of $4 \mathrm{mg} / \mathrm{dm}^{3}-0.61$. That is, the greatest rate of deposition is demonstrated by aggregates formed with the combined use of bentonite clay and flocculant.

2. As a result of the processing of sediment curves, we found that during the purification of phenolic wastewater, we get pollutant-containing aggregates of the following prevailing radii, $\mu \mathrm{m}: \mathrm{Al}_{2}(\mathrm{OH})_{5} \mathrm{Cl}$ at a dosage of $50 \mathrm{mg} / \mathrm{dm}^{3}-30 \ldots 90 ; \mathrm{FeCl}_{3}$ at a dosage of $50 \mathrm{mg} / \mathrm{dm}^{3}-$ 33...39; Extrafloc P70 at a dosage of $4 \mathrm{mg} / \mathrm{dm}^{3}-60 \ldots 80$; bentonite clay at a dosage of $100 \mathrm{mg} / \mathrm{dm}^{3}-23 \ldots 27$; bentonite clay at a dosage of $100 \mathrm{mg} / \mathrm{dm}^{3}$ with the addition of Extrafloc P70 at a dosage of $4 \mathrm{mg} / \mathrm{dm}^{3}-70 \ldots 90$.

3. Comparative analysis of sedimentation rate and geometrical sizes of pollutant-containing aggregates shows that the most effective method for purification of phenolic wastewater of coke-chemical enterprises is the combined use of alkaline bentonite clay with a dosage of $100 \mathrm{mg} / \mathrm{dm}^{3}$ and a cationic flocculant Extrafloc P70 at a dosage of $4 \mathrm{mg} / \mathrm{dm}^{3}$. This method provides the largest integrated sedimentation rate of aggregates $0.61 \mathrm{mg} / \mathrm{s}$ and intensive water clarification in 1-3 min. In this case, we achieve a high degree of purification of wastewater from resinous substances $-96 \%$.

\section{References}

1. Klymenko, I. Developing of effective treatment technology of the phenolic wastewater [Text] / I. Klymenko, D. Yelatontsev, A. Ivanchenko, O. Dupenko, N. Voloshyn // Eastern-European Journal of Enterprise Technologies. - 2016. - Vol. 3, Issue 10 (81). P. 29-34. doi: 10.15587/1729-4061.2016.72410

2. Ivanchenko, A. V. Researching the technology of tar removal from coke-chemical plants' wastewater by reagent flotation method [Text] / A. V. Ivanchenko, D. O. Yelatontsev, M. D. Voloshin, O. O. Dupenko // Odes'kyi Politechnichnyi Universytet. Pratsi. 2015. - Issue 1 (45). - P. 158-163. doi: 10.15276/opu.1.45.2015.26

3. Pat. No. 111944 UA. The method cleaning phenolic wastewater from coal tar. MPK C02F 1/24, B03D 1/02 [Text]/Yelatontsev D. O., Ivanchenko A. V., Voloshin M. D. - No. u201605987; declareted: 02.06.2016; published: 25.11.2016, Bul. No. 22.

4. Chaudhari, P. K. Treatment of coke oven effluent by coagulation process [Text] / P. K. Chaudhari, R. Chaudhary // International Journal of ChemTech Research. - 2016. - Vol. 9, Issue 3. - P. 640-644.

5. Lee, C. S. A review on application of flocculants in wastewater treatment [Text] / C. S. Lee, J. Robinson, M. F. Chong // Process Safety and Environmental Protection. - 2014. - Vol. 92, Issue 6. - P. 489-508. doi: 10.1016/j.psep.2014.04.010 
6. Kaya, E. M. Ö. Adsorption kinetics and isotherm parameters of naphthalene onto natural- and chemically modified bentonite from aqueous solutions [Text] / E. M. Ö. Kaya, A. S. Özcan, Ö. Gök, A. Özcan // Adsorption. - 2013. - Vol. 19, Issue 2-4. - P. 879-888. doi: 10.1007/s10450-013-9542-3

7. Nourmoradi, H. Multi-Component Adsorption of Benzene, Toluene, Ethylbenzene, and Xylene from Aqueous Solutions by Montmorillonite Modified with Tetradecyl Trimethyl Ammonium Bromide [Text] / H. Nourmoradi, M. Khiadani, M. Nikaeen // Journal of Chemistry. - 2013. - Vol. 2013. - P. 1-10. doi: 10.1155/2013/589354

8. Pasternak, A. A. Dispersionnyy analiz nadsmol'nykh vod koksokhimicheskogo proizvodstva [Dispersive analysis of tarry wastewater in coke production] [Text] / A. A. Pasternak, N. Yu. Andreyev, V. P. Belonoshchenko, L. P. Bannikov // UgleKhimicheskiy zhurnal. 2013. - Issue 5. - P. 64-70. - Available at: http://nbuv.gov.ua/UJRN/ukhj_2013_5_14

9. Liu, D. M. Experimental Study of Organic Pollutants in Waste Water from the Coking Plant Adsorbed by Organobentonite [Text] / D. M. Liu, B. K. Jiang // Advanced Materials Research. - 2011. - Vol. 402. - P. 747-752. doi: 10.4028/www.scientific.net/ amr.402.747

10. Mirmohamadsadeghi, S. An efficient method for clay modification and its application for phenol removal from wastewater [Text] / S. Mirmohamadsadeghi, T. Kaghazchi, M. Soleimani, N. Asasian // Applied Clay Science. - 2012. - Vol. 59-60. - P. 8-12. doi: 10.1016/j.clay.2012.02.016

11. Owabor, C. N. Enhanced Sorption of Naphthalene onto a Modified Clay Adsorbent: Effect of Acid, Base and Salt Modifications of Clay on Sorption Kinetics [Text] / C. N. Owabor, U. M. Ono, A. Isuekevbo // Advances in Chemical Engineering and Science. 2012. - Vol. 02, Issue 03. - P. 330-335. doi: 10.4236/aces.2012.23038

12. Kirbaba, V. V. Nailuchshiye dostupnyye tekhnologii i ih vnedreniye na PAO «Avdeyevskiy koksokhimicheskiy zavod» [The best available techniques and their implementation at PJSC «Avdiivka Coke»] [Text] / V. V. Kirbaba, A. S. Malysh, A. L. Borisenko, N. I. Avilova, K. Ye. German // UgleKhimicheskiy zhurnal. - 2013. - Issue 5. - P. 83-89. - Available at: http://nbuv.gov.ua/UJRN/ ukhj_2013_5_17

13. Ismail, I. M. Combined coagulation flocculation pre treatment unit for municipal wastewater [Text] / I. M. Ismail, A. S. Fawzy, N. M. Abdel-Monem, M. H. Mahmoud, M. A. El-Halwany // Journal of Advanced Research. - 2012. - Vol. 3, Issue 4. - P. 331-336. doi: 10.1016/j.jare.2011.10.004

14. Frolov, Yu. G. Laboratornyye raboty i zadachi po kolloidnoy khimii [Laboratory work and tasks on colloid chemistry] [Text] / Yu. G. Frolov; Yu. G. Frolov, A. S. Grodskoy (Eds.). - Moscow: Khimiya, 1986. - 216 p. 